\title{
The Influence of Time Delay and Serial Position on Story Retelling Abilities in the Elderly with Subjective Memory Impairments
}

\author{
JuHyeon Kim, JungWan Kim \\ Department of Speech Pathology, College of Rehabilitation Sciences, Daegu University, Gyeongsan, Korea
}

\author{
기억 지연 유무 및 서열위치 효과에 따른 주관적 기억장애 노인의 이야기 다시 말하기 수행력 \\ 김 주 현·김 정 완 \\ 대구대학교 재활과학대학 언어치료학과
}

\begin{abstract}
Purpose: As the conversion rate of degenerative dementia in the elderly with subjective memory impairments (SMI) has been reported to be high, the attempts to examine their cognitive-linguistic abilities and compare with normal elderly (NE) have drawn attention. This study has executed the story retelling task, frequently used as a subcategory of memory test, to NE and elderly with SMI, and conducted a comparative analysis of the performance according to time delay and serial position. Methods: The stories composed of a total of 18 information units (IU) were told to a total of 80 elderly ( $\mathrm{NE}=40, \mathrm{SMI}=40$ ), and immediate and delayed recall was conducted. Results: The IU recall rate (\%) of SMI was significantly lower than that of NE ( $F=116.482, p<0.001)$, and the IU recall rate (\%) was significantly lower for delayed recall than for immediate recall $(F=9.460, p<0.01)$, and the intermediate position showed a significantly higher IU recall rate $(\%)$ compared to the primacy position ( $F=4.138, p<0.05)$. Conclusion: SMI, unlike NE, showed difficulty in using rehearsal strategy or storing new information, which indicates that some parts of the meta-cognitive function can have negative influences in SMI stages as well.
\end{abstract}

Key Words: Subjective memory impairments, Story retelling, Information units, Serial position, Time delay.

Received: August 4, 2019 / Revised: September 11, 2019 / Accepted: September 12, 2019

Correspondence: JungWan Kim, Department of Speech Pathology, College of Rehabilitation Sciences, Daegu University, 201 Daegudae-ro, Jillyang-eup, Gyeongsan 38453, Korea

Tel: +82-53-850-4325 / Fax: +82-53-850-4329 / E-mail: kimjungwan@daegu.ac.kr

\section{INTRODUCTION}

노화가 진행됨에 따라 노인들은 일상생활에서 기억력 문제 를 호소하는 빈도가 점점 증가한다. 기억력 문제가 알츠하이머 치매(Alzheimer's disease, $\mathrm{AD}$ )의 주 증상이라는 대중적인 인 식 때문에 $\mathrm{AD}$ 에 대한 불안감으로 기억력 저하를 호소하며 병 원을 내원하는 환자들의 수가 점점 늘어나고 있는 추세이다. 그 러한 사람들 중 객관적인 신경심리검사에서는 정상 범위이지 만, 일상생활에서만 '건망증'과 같은 기억력 문제를 호소하는

(c) This is an Open Access article distributed under the terms of the Creative Commons Attribution Non-Commercial License (https://creativecommons.org/licenses/by-nc/4.0) which permits unrestricted non-commercial use, distribution, and reproduction in any medium, provided the original work is properly cited.
사람들이 있다. 최근 이러한 사람들에 대한 연구가 활발히 진행 중이며, 이러한 사람들을 '주관적 기억장애(subjective memory impairments, SMI)로 명명하고 있다. 현재 SMI에 대한 정확한 임상적 정의는 합의된 바가 없다. 하지만 최근 $\mathrm{SMI}$ 에 대한 높 아진 관심을 반영하듯이, Abdulrab \& Heun(2008)은 SMI를 주제로 한 44개의 논문들을 바탕으로 $\mathrm{SMI}$ 의 진단 준거에 포함 되어야 할 포괄적인 필수 내용들을 제안하였다. 이들이 주장한 필수 요인들은 다음과 같다: 1) 발병 연령이 50대 이상이어야 함. 2) 6개월 이상 지속적으로 기억력 문제를 호소해야 함. 3) 현 재 자신의 기억력이 5 10년 전에 비해 저하되었다고 생각하여 야 함. 4) 일상생활에서 발생하는 기억력 문제의 생생한 예를 들 수 있어야 함. 5) 1주일에 한 번 이상 기억력 문제가 발생해야 
함. 6) 객관적인 평가에서는 기억력이 정상 범주에 속해야 함 (Kim, 2018). SMI를 대상으로 높아진 연구적 관심은 SMI가 경도인지장애(mild cognitive impairment, $\mathrm{MCI}$ )와 $\mathrm{AD}$ 를 예측 할 수 있는 주요 인자가 될 수 있다는 보고 때문이다(Mitchell, 2008). Tobiansky et al.(1995)은 SMI를 대상으로 추적 관찰을 실시한 결과, 이들의 치매 발병률이 정상 노인보다 2 배 정도 높 았다고 보고하였다.

노화가 진행되면서 노인은 생물학적 노화와 함께 인지기능의 저하를 경험하게 된다. 이러한 인지기능의 저하로 인해 노인은 복잡하고 정교함이 요구되는 주의력 과제를 처리하는 과정에 어려움을 보이고(Kim et al., 2013), 이 외에도 기억력, 언어능력 에서도 감퇴를 경험하게 된다(Lee et al., 2012). 이러한 인지적 저하는 연속발화(connected speech)에서의 변화로 이어진다. 노인은 청·장년층에 비해 주제와 관련 없는 이야기를 하는 경 우가 많고, 이야기의 응집성이 떨어지며, 그로 인해 이야기 다시 말하기에서 낮은 수행력을 보인다고 한다(Kim \& Sung, 2014).

연속발화를 수집하는 방법은 연구자에 따라 다양하며, 최근 체크리스트를 통해 담화를 분석하는 정보단위(information unit, IU) 분석 체계가 실어증과 같은 신경 언어장애 환자를 대 상으로 활발히 활용되고 있는 추세이다(McNeil et al., 2001). $\mathrm{IU}$ 는 이야기와 관련 있는 정보를 전달하는 단어나 어절을 말 한다. 목표 IU가 미리 정해져 있으며, 대상자가 다시 말하는 이 야기를 들으며 체크리스트를 통해 IU를 채점한다. 동의어는 정 답으로 인정하며, 동의어에는 대명사와 명사, 고유명사, 동사, 형용사, 부사, 접속사, 조사가 포함된다. 이 방법은 대상자의 발 화를 수집한 후 전사하지 않아도 된다는 점에서 효율적인 연구 방법으로 보고되고 있다(Kim \& Sung, 2014).

IU 채점을 통한 담화 분석 연구는 서열위치효과(serial position effect)를 함께 확인하는 연구도 진행되어 왔다. 서열위치 효과란 언어 회상 과제에서 기억해야 할 이야기의 중반부(이하 중간위치)보다 이야기의 전반부(이하 초두위치)와 이야기의 후 반부(이하 최신위치)에 제시된 부분을 더 잘 기억하는 현상을 말한다(Capitani et al., 1992). 초두위치에 제시된 이야기를 중 간위치에 제시된 이야기보다 더 잘 회상하는 현상을 초두효과 (primacy effect)라고 하고, 반대로 후반부에 제시된 이야기를 중반부에 제시된 이야기보다 더 잘 회상하는 현상을 최신효과 (recency effect)라고 한다. 초두효과와 최신효과는 이야기를 회상할 때 기억할 수 있는 용량(span)에 한계(limitation)를 넘 어서는 경우에 발생하는 현상으로, 이야기 다시 말하기 과제에 서 서열위치와 이야기 회상률을 그래프로 나타내면 U 자 형태 를 보이게 된다(Murdock, 1962). 서열위치효과는 노화에 따라 초두효과나 최신효과의 관찰이 뚜렷하지 않게 나타난다는 연 구가 보고되고 있다(Arenberg, 1976; Capitani et al., 1992;
Parkinson et al., 1982; Salthouse, 1980; Wright, 1982).

수집된 담화는 기억 지연 유무에 따라 즉각회상과 지연회상 으로 나누어 살펴볼 수도 있다. 즉각회상은 제시된 이야기를 지 연시간 없이 바로 회상하는 것을 말하며, 시연 과정(rehearsal process)과 관련이 있고 부호화(encoding) 정도를 파악할 수 있 다(Jung, 2014). 반대로 지연회상은 제시된 이야기를 일정 시간 지 연한 후에 회상하는 것을 말하며, 인출 과정(retrieval)을 파악 하여 인지 손상의 정도를 예측할 수 있다고 본다(Bruno et al., 2013).

선행연구에 따르면 정상 노인과 $\mathrm{MCI}$ 를 변별하는 데 서열위 치효과에 따른 분석이 $\mathrm{MCI}$ 의 민감한 예측 인자가 될 수 있으 며(La Rue et al., 2008), 지연회상에서 서열위치효과를 파악하 였을 때 $\mathrm{AD}$ 위험군을 효과적으로 변별할 수 있다고 하였다 (Baddeley \& Warrington, 1970; Bruno et al., 2013; Walsh et al., 2014). 이렇게 $\mathrm{MCI}$ 와 $\mathrm{AD}$ 의 담화 능력에 대한 연구는 종종 이루어져 왔으나, SMI의 경우 객관적인 신경심리검사상 정상인 경우가 많고, 주관적인 기억 불만을 호소하더라도 임상 전 (preclinical) 단계인 경우가 많아 담화 능력을 살펴보기 위한 연구 기반이 확보되기 어려웠다. 따라서 본 연구에서는 이야기 회상 과제에서 나타난 정상 노인과 SMI의 수행력을 서열위치와 기억 지연 유무에 따라 비교·분석해 봄으로써 SMI가 호소하는 주관적 기억장애가 인지의 광범위한 영역의 손상을 알아볼 수 있는 이야기 회상 과제에서 어떻게 발현되는지 그 차이를 확인 하고, 향후 다시 말하기 방식을 활용한 이야기 회상 과제가 SMI 에 대한 조기 선별평가로서 사용 가능한지 그 가능성을 확인해 보고자 하였다.

\section{MATERIALS AND METHODS}

\section{연구 대상}

본 연구는 대구/경북 지역에 거주하고 있는 65 세 이상의 정 상 노인 40명과 SMI 40명을 대상으로 실시하였다. 이들 대부분 은 경산시 소재 노인 복지관 1곳과 마을회관 3 곳에서 표집되었 고, 대구 지역의 노인정 대상자들도 포함되었다. 연구자는 사전 에 피험자들에게 연구 목적 및 절차에 대한 상세한 설명을 하 였으며, 먼저 간단한 인터뷰를 통하여 신경학적·정신적 질병이 없는 것을 확인한 후, 피험자들의 참여 동의를 얻은 다음 실험 을 실시하였다. 실험 전 기본적인 청력 상태를 파악하기 위해 인터뷰상 재질문이 없고, 검사자의 질문에 즉각 응답이 가능하 며, 보청기를 끼지 않았거나 보청기를 착용 중이더라도 조정된 청력이 일상적인 대화에 어려움을 초래하지 않는 상태의 피험 자들로만 선별하였다. 모든 피험자들은 1) 한국판 단축형 노인 우울척도(geriatric depression scale short form Korean ver- 
sion, GDSSF-K) (Kee, 1996) 검사 결과 우울감이 없고, 2) 한 국형 간이 정신상태검사(Korean-Mini Mental State Examination, K-MMSE) (Kang, 2006) 결과 정상 범위의 인기지능을 보이며, 3) 신경학적, 정신적 질병이 없는 자들을 대상으로 하였 다. 이 중 SMI 선별을 위해 Abdulrab \& Heun(2008)이 제시한 진단 준거를 토대로 $\mathrm{SMI}$ 집단을 선별하였으며, 진단기준은 다 음과 같다.

$\mathrm{SMI}$ 는 1) 뇌의 구조적/기능적 이상이나 정신과적 질병이 없 는 자, 2) 6개월 이상 지속적으로 기억력 문제를 호소하는 자, 3) 현재의 기억력이 5 10년 전에 비해 저하되었다고 생각하는 자, 4) 일상생활에서 발생하는 기억력 문제에 대한 생생한 예시 를 들 수 있는 자, 5) 적어도 일주일에 한 번 이상 기억력 문제 가 발생하는 자들로 선별하였다. 위 사항들은 사전 인터뷰 시 검사자가 일대일로 물어보고 선별기준에 해당되는 자들로만 선 정하였다.

모든 피험자들은 과제 수행을 위해 시력과 청력에 문제가 없 는 자로 선정하였으며, 두 집단 간 교육 기간 $(\mathrm{F}=0.714, p>0.05)$ 및 연령 $(\mathrm{F}=0.318, p>0.05)$ 의 동질성은 확보되었다. 두 집단의 인구통계학적 특성은 Table 1에 제시하였다.

\section{실험 도구}

\section{한국판 간이 정신상태검사}

Mini Mental State Examination은 연구 및 임상평가에서 전 세계적으로 널리 사용되고 있는 치매 선별 도구이다. 우리나 라에서도 K-MMSE (Kang et al., 1997)가 제작되어 널리 쓰이 고 있다. 본 연구에서 피험자들의 인지기능이 정상 수준에 해 당하는지 확인하고, $\mathrm{AD}$ 나 $\mathrm{MCI}$ 의 가능성을 배제하기 위하여 $\mathrm{K}-\mathrm{MMSE}$ 를 실시하였으며, $\mathrm{Kang}$ (2006)의 K-MMSE 노인 규 준을 참고하여 대상자를 선별하였다.

\section{한국판 노인우울척도 단축형}

노인의 우울 정도를 측정하기 위해서 geriatric depression scale short form (Yesavage et al., 1983)을 Kee(1996)가 번안 하여 표준화한 한국판 노인우울척도 단축형(GDSSF-K)을 사 용하였다. GDSSF-K는 15 문항으로 구성되어 있으며, 우울증과 관련된 각 질문에 대해 ‘예’나 ‘아니오'로 응답하도록 되어 있다.

Table 1. Demographic characteristics in two groups

\begin{tabular}{lcc}
\hline \multicolumn{1}{c}{ Characteristic } & NE $(\mathrm{n}=40)$ & SMI $(\mathrm{n}=40)$ \\
\hline Age $(\mathrm{yr})$ & $76.87( \pm 6.83)$ & $77.88( \pm 6.54)$ \\
Gender (m:f) & $10: 30$ & $8: 32$ \\
Level of education $(\mathrm{yr})$ & $5.82( \pm 4.22)$ & $5.28( \pm 4.18)$ \\
\hline
\end{tabular}

NE: normal elderly, SMI: subjective memory impairments
본 연구에서는 절단점인 8점을 기준으로 피험자들의 우울 수 준을 확인하고, 우울함이 있는 피험자는 제외하였다.

\section{이야기 회상 과제}

Joanette et al.(2004)의 Montreal protocol for the evaluation of communication을 Woo \& Kim(2019)이 번안한 한국 판 몬트리올 의사소통 평가 도구에 포함되어 있는 하위 담화 과제인 '우물 이야기'를 선정하였다. 이야기를 원본 그대로 사용 하지 않고, 20 대 정상 청년 10명을 대상으로 이야기 다시 말하 기 예비실험을 실시하였으며, 그중 주로 산출한 문장이나 어절 을 토대로 이야기를 축약하였다(Appendix 1).

\section{연구 절차}

먼저 간단한 인터뷰를 통하여 신경학적·정신적 질병이 없는 것을 확인한 후, K-MMSE와 GDSSF-K를 실시하여 인지기능 저하와 우울함이 없는 사람들을 피험자로 선정하였다. 그중 $\mathrm{SMI}$ 를 선별하는 질문지를 통해 주관적 기억 불만을 호소하는 피험자는 SMI 집단, 그렇지 않은 피험자는 정상 노인 집단으로 분류하였다.

연구자는 피험자에게 6컷의 그림(Appendix 2)과 함께 "지금 부터 제가 이야기를 2 번 들려드리겠습니다. 그림을 보시면서 이 야기를 들으시고 이야기가 끝난 후 제게 다시 이야기해 주세요." 라고 과제를 설명한 다음, 이야기를 2번 들려주었다. 이야기를 들려준 후 그림 없이 이야기를 즉각회상(1차 수행)하도록 유도 하였고, 20 분 후에 실험의 마지막 절차로 이야기를 지연회상(2 차 수행)하도록 하였다.

실험은 소음이 통제된 곳에서 실시하였으며, 대상자의 반응 은 모두 스마트폰(Galaxy Note 8, Samsung, Suwon, Korea) 녹음기를 이용하여 녹음한 후 2일 이내에 전사하여 분석하였다.

본 연구에서 사용한 우물 이야기는 총 18 개의 IU로 이루어 져 있으며, 초두위치 6개, 중간위치 6개, 최신위치 6개로 각각 이루어져 있다. 즉각회상의 회상률은 전체 IU 수에서 각각의 위치(초두위치, 중간위치, 최신위치)에서 회상한 IU 수의 비율 로 백분율로 환산하였다. 각 IU의 최고 회상률은 $33.3 \%$ 였고, 지연회상의 회상률 계산 또한 즉각회상과 동일하게 하였다.

\section{통계 분석}

본 연구의 연구 문제에 따라 이야기 회상 과제에서 기억 지연 유무 및 서열위치에 따른 정상 노인과 SMI 간에 IU 회상률에 유의한 차이를 알아보기 위해 삼원혼합분산분석[three-way mixed analysis of variance (ANOVA)]을 실시하였다. 본 연구 에서는 SPSS Statistics 25.0 (IBM Corp., Armonk, NY, USA) 을 사용하여 자료 분석을 실시하였다. 추가적으로 기억 지연 
유무에 따른 IU 회상률의 유의한 차이를 알아보기 위해 독립 표본 $t$ 검정을 추가로 실시하였다.

\section{RESULTS}

\section{이야기 회상 과제에서 기억 지연 유무 및 서열위치에 따른}

\section{집단 간 IU 회상률}

이야기 회상 과제 시, 기억 지연 유무 및 서열위치에 따른 집 단 간 IU 회상률(\%)의 차이가 유의한지를 알아보기 위하여 삼 원혼합분산분석(three-way mixed ANOVA)을 실시하였다. 이
야기 회상 과제에서 기억 지연 유무 및 서열위치에 따른 집단 간 차이에 대한 평균 및 표준편차는 Table 2와 Figure 1에 제시 하였다.

삼원혼합분산분석(three-way mixed ANOVA) 검정을 실시 한 결과는 Table 3 에 제시하였다.

집단에 대한 주 효과가 유의하였다 $(\mathrm{F}=116.482, p<0.001)$. 즉 $\mathrm{SMI}$ 의 $\mathrm{IU}$ 회상률(\%)이 정상 노인의 $\mathrm{IU}$ 회상률(\%)에 비해 유의하게 낮은 것으로 나타났다. 기억 지연 유무에 대한 주 효 과가 유의하였다 $(\mathrm{F}=9.460, p<0.01)$. 즉 지연회상에서 IU 회 상률(\%)이 즉각회상에서보다 유의하게 낮은 것으로 나타났다.

Table 2. Descriptive statistics on IU recall rate (\%) between groups according to time delay and serial position in story retelling performance

\begin{tabular}{clcc}
\hline Time delay & Serial position & NE $(\mathrm{n}=40)$ & SMI $(\mathrm{n}=40)$ \\
\hline Immediate recall & Primacy & $47.50( \pm 19.077)$ & $31.66( \pm 22.895)$ \\
& Intermediate & $63.75( \pm 23.836)$ & $30.83( \pm 29.368)$ \\
& Recency & $57.91( \pm 36.198)$ & $29.16( \pm 34.745)$ \\
Delayed recall & Total & $56.38( \pm 27.937)$ & $30.55( \pm 29.175)$ \\
& Initial position & $45.00( \pm 18.179)$ & $22.91( \pm 24.368)$ \\
& Intermediate & $61.25( \pm 25.981)$ & $22.91( \pm 27.654)$ \\
& Recency & $42.91( \pm 29.207)$ & $20.00( \pm 28.793)$ \\
\hline
\end{tabular}

Mean ( \pm standard deviation). IU: information unit, NE: normal elderly, SMI: subjective memory impairment
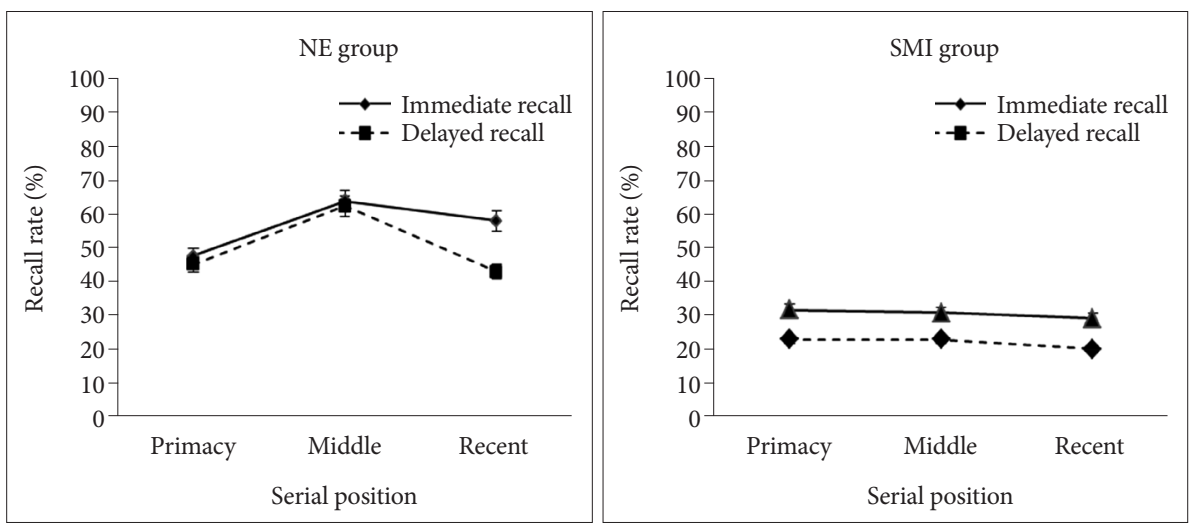

Figure 1. Information unit recall rate (\%) between groups according to time recall and serial position in story retelling performance. NE: normal elderly, SMI: subjective memory impairment.

Table 3. Analysis of variance of IU recall rate (\%) between groups according to time delay and serial position in story recall task

\begin{tabular}{lrrrr}
\hline & SS & df & MS & F \\
\hline Between group & & & & \\
$\quad$ Group & $86,224.537$ & 1 & $86,224.537$ & \\
$\quad$ Error & $346,430.556$ & 468 & 740.236 \\
Within group & & & \\
$\quad$ Recall time & $7,002.315$ & 1 & $7,002.315$ & $9.460^{\dagger}$ \\
Group $\times$ recall time & 113.426 & 1 & 113.426 & 0.153 \\
Serial position & $6,126.157$ & 2 & $3,063.079$ & $4.138^{*}$ \\
Group $\times$ serial position & $5,612.269$ & 2 & $2,806.134$ & $3.791^{*}$ \\
Recall time $\times$ serial position & $1,188.657$ & 2 & 594.329 & 0.803 \\
Group $\times$ recall time $\times$ serial position & 910.880 & 2 & 445.440 & 0.615 \\
\hline
\end{tabular}

${ }^{*} p<0.05,{ }^{\dagger} p<0.01,{ }^{*} p<0.001$. IU: information unit 
서열위치에 따른 주 효과가 유의하였다( $\mathrm{F}=4.138, p<0.05)$. 서열위치에 따른 IU 회상률(\%)의 Bonferroni 사후 검정을 실 시한 결과, 중간위치에서 IU 회상률(\%)이 초두위치에서 IU 회 상률 $(\%)$ 보다 유의하게 높았다 $(p<0.05)$. 하지만 중간위치와 최신위치 $(p>0.05)$, 최신위치와 초두위치 $(p>0.05)$ 간에는 차이가 없는 것으로 나타났다.

집단과 서열위치 간의 상호작용 효과가 통계적으로 유의하였 다(F $=3.791, p<0.05)$. 이는 $\mathrm{SMI}$ 보다 정상 노인에서 서열위 치 간 IU 회상률(\%)의 차이가 더 컸기 때문인 것으로 나타났다. 집단과 서열위치의 상호작용 효과를 보여주는 그래프는 Figure 2 와 같다.

추가적으로 기억 지연 유무에 따른 집단 간 차이가 유의한지 알아보기 위해 독립표본 $t$ 검정을 실시한 결과, 즉각회상에서 집단 간 IU 회상률 차이가 유의하였다 $(\mathrm{F}=0.220, p<0.001)$. 또 한 지연회상에서도 집단 간 $\mathrm{IU}$ 회상률 차이가 유의하였다 $(\mathrm{F}=$ $0.723, p<0.001)$. 즉, 즉각 및 지연회상에서 $\mathrm{SMI}$ 의 IU 회상률 이 정상 노인의 IU 회상률보다 낮게 나타났다(Table 4).

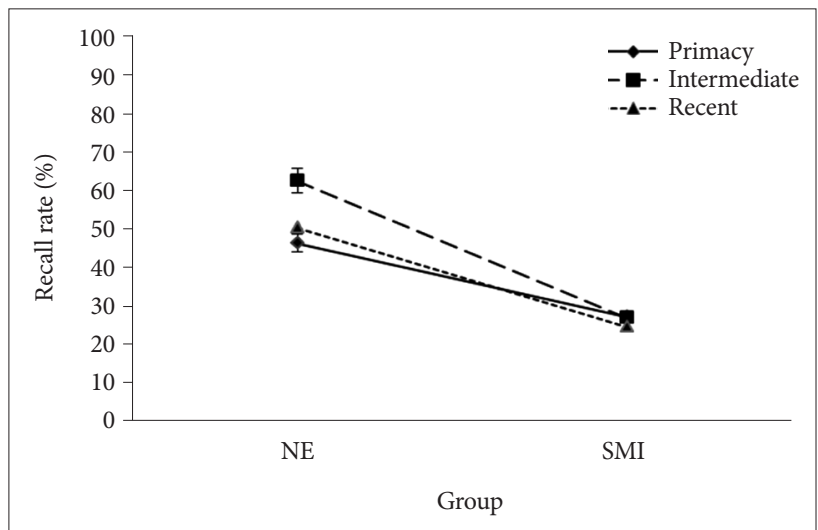

Figure 2. Interaction between group and serial position. NE: normal elderly, SMI: subjective memory impairment.

\section{SMI에서 회상시점에 따른 서열위치별 IU 회상률}

$\mathrm{SMI}$ 에서 회상시점에 따른 서열위치별 IU 회상률의 차이가 유의한지 살펴보기 위해 일변량분산분석(one-way ANOVA) 을 각각 실시하였다. 이에 대한 기술 통계와 도표는 Table 5 및 Figure 3과 같다.

$\mathrm{SMI}$ 에서 즉각회상 시, 서열위치에 따른 IU 회상률의 차이가 통계적으로 유의하지 않았다 $(\mathrm{F}=0.075, p>0.05)$. 서열위치에 따른 IU 회상률의 Bonferroni 사후검정을 실시한 결과, 초두 위치와 중간위치 $(p>0.05)$, 중간위치와 최신위치 $(p>0.05)$, 초 두위치와 최신위치 $(p>0.05)$ 간의 차이가 통계적으로 모두 유 의하지 않았다. SMI에서 지연회상 시, 서열위치에 따른 IU 회상 률의 차이는 통계적으로 유의하지 않았다 $(\mathrm{F}=0.156, p>0.05)$. 서열위치에 따른 IU 회상률의 Bonferroni 사후검정을 실시한 결 과, 초두위치와 중간위치 $(p>0.05)$, 중간위치와 최신위치 $(p>$ $0.05)$, 초두위치와 최신위치 $(p>0.05)$ 간의 차이가 통계적으로 모두 유의하지 않았다. SMI에서 서열위치에 따른 회상시점 간 에 차이가 유의한지 알아보기 위해 독립표본 $t$ 검정을 실시한 결과, 초두위치 $(\mathrm{F}=3.42, p>0.05)$, 중간위치 $(\mathrm{F}=0.039, p>$

Table 4. The results of $t$-test of IU recall rates (\%) between two groups by recall time

\begin{tabular}{lccc}
\hline \multicolumn{1}{c}{ Recall time } & NE & SMI & $p$-value \\
\hline Immediate recall & $56.38( \pm 27.93)$ & $30.55( \pm 29.17)$ & 0.000 \\
Delayed recall & $49.72( \pm 26.01)$ & $21.94( \pm 26.81)$ & 0.000 \\
\hline
\end{tabular}

Mean ( \pm standard deviation). IU: information unit, NE: normal elderly, SMI: subjective memory impairment

Table 5. IU recall rate (\%) by serial position in SMI

\begin{tabular}{lcc}
\hline Serial position & Immediate recall & Delayed recall \\
\hline Primacy & $31.66( \pm 22.895)$ & $22.91( \pm 24.368)$ \\
Intermediate & $30.83( \pm 29.368)$ & $22.91( \pm 27.654)$ \\
Recency & $29.16( \pm 34.745)$ & $20.00( \pm 28.793)$ \\
\hline
\end{tabular}

Mean ( \pm standard deviation). IU: information unit, SMI: subjective memory impairment
Figure 3. IU recall rate $(\%)$ by serial position according to recall time. SMI: subjective memory impairment, IU: information unit.
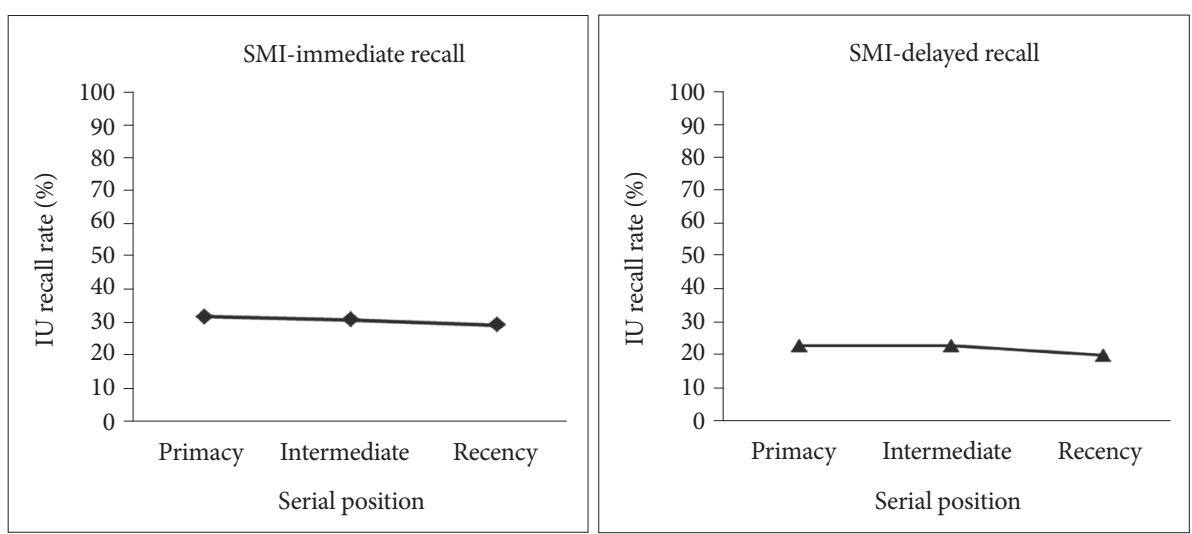
$0.05)$, 최신위치 $(\mathrm{F}=3.050, p>0.05)$ 모두 유의한 차이가 관찰 되지 않았다.

\section{DISCUSSIONS}

본 연구의 목적은 이야기 회상 과제에서 기억 지연 유무 및 서열위치에 따른 정상 노인과 SMI 간 IU 회상률에 차이가 있 는지 알아보는 것이었다. 본 연구 결과를 '이야기 회상 과제에 서 집단 간 IU 회상률 차이', '기억 지연 유무에 따른 집단 간 IU 회상률 차이', '서열위치에 따른 집단 간 IU 회상률 차이'로 나누어 자세히 논의하고자 한다.

\section{이야기 회상 과제에서 집단 간 IU 회상률 차이}

집단에 따라 IU 회상률의 차이를 살펴본 결과 집단 간 $\mathrm{IU}$ 회상률의 차이가 유의하였다. 즉, SMI가 정상 노인보다 회상한 $\mathrm{IU}$ 수가 더 적은 것으로 나타났다.

이는 SMI와 정상 노인을 대상으로 객관적인 신경심리검사를 실시한 결과, SMI가 정상 노인보다 기억력 영역에서 낮은 수행력 을 보였다는 선행연구의 결과와 일치하였다(Jessen et al., 2006).

국외의 한 선행연구에서는 $\mathrm{SMI}$ 가 $\mathrm{AD}$ 이전 경미한 $\mathrm{MCI}$ 의 전조 단계로서 점차 주목을 받고 있으므로, $\mathrm{SMI}$ 에서 $\mathrm{AD}$ 로 발 병되는 정도를 알아보기 위해 75세 이상의 인지기능에 문제가 없는 노인 2,415명을 대상으로 1년 6개월 후, 3년 후에 추적 관 찰을 실시하였다. 그 결과 두 번의 추적 관찰 모두에서 자신의 기억력 저하를 걱정하는 $\mathrm{SMI}$ 가 정상 노인에 비해 $\mathrm{AD}$ 로 발병 될 위험성이 훨씬 컸다고 보고하였다(Jessen et al., 2010).

앞선 선행연구에서 SMI가 정상 노인보다 기억력 영역에서 낮은 점수를 보였던 것과 같이, 본 연구에서도 SMI가 정상 노 인보다 이야기를 기억한 후 회상하는 이야기 다시 말하기 과제 에서 낮은 수행력을 보인다는 것을 확인할 수 있었다.

\section{기억 지연 유무에 따른 집단 간 IU 회상률 차이}

본 연구의 연구 문제는 집단과 회상시점에 따른 IU 회상률의 차이를 살펴본 결과, 집단과 회상시점에 대한 상호작용은 통계 적으로 유의하지 않았다. 하지만 추가로 회상시점에 따른 집단 간 IU 회상률의 차이가 유의한지 알아보기 위해 $t$ 검정을 실시 한 결과, 즉각회상 및 지연회상 모두에서 SMI가 정상 노인보다 낮은 IU 회상률을 보였다. 즉 집단 내에서 회상시점에 따른 IU 회상률의 격차는 집단 간 차이를 보이지 않았다.

즉각회상에서 회상률은 시연과 응고화를 반영한다. 시연은 기억이 쉽게 사라지지 않는 형태로 저장되도록 돕는 역할을 하 며, 장기기억까지 되는 시간의 의존적인 기억 저장 과정을 응고 화라고 한다(Kang \& Baek, 2014). 한 국외 연구에서는 정상 성
인을 대상으로 즉각회상에서 시연 방법에 따른 단어 회상률을 알아보았는데, 시연을 하였을 때 단어 회상률이 더 높았다고 보 고하였다(Tan \& Ward, 2008). 또 다른 연구에서는 MCI가 정 상 노인보다 시연을 하는 데 어려움을 겪는다고 하였다(Ribeiro et al., 2007). 따라서 본 연구에서 SMI는 정상 노인보다 상대적 으로 시연을 사용하는 데 미흡하여 이야기를 단기 및 장기기억 으로 저장하는 능력에 어려움을 겪은 것으로 해석할 수 있다.

지연회상에서 회상률은 정보를 응고화하여 인출하는 과정 을 파악할 수 있다. Walsh et al.(2014)은 이야기 학습 과제(stoty learnig task)를 정상 노인과 $\mathrm{MCI}$ 를 대상으로 실시하였다. 연구자는 회상시점을 30 분 후와 1 주일 후로 설정하여 지연 시 간에 따른 이야기 회상률을 살펴보았으며, 그 결과 집단과 회상 시점에 따른 상호작용에서 집단 간 유의한 차이를 보고하였다. 이러한 집단 간 차이는 응고화 능력 차이에 의해 발생한 것으 로 해석할 수 있다.

$\mathrm{SMI}$ 를 대상으로 종합적인 서울 신경심리검사(Soeul Neuropsychological Screening Battery)를 실시한 국내 연구에서는 $\mathrm{SMI}$ 가 언어학습검사 중 지연회상에서 정상 노인에 비해 낮은 수행력을 보였다고 보고하였다(Kang \& Baek, 2014). Takaya$\mathrm{ma}(2010)$ 는 정상 노인, $\mathrm{MCI}, \mathrm{AD}$ 를 대상으로 단어 회상 과제, 이야기회상검사, 그림회상검사를 실시하였다. 10년 후 재평가를 실시한 결과 3 개의 지연회상검사가 $\mathrm{MCI}$ 와 $\mathrm{AD}$ 를 효과적으로 예측할 수 있다고 하였다. 이에 대해 연구 과제와 비슷한 성격 의 언어적 방해 과제가 제시되었을 때 인지 부하가 많아지면서 기존에 주어진 언어 정보가 쇠퇴(decay)하게 될 가능성이 커지 므로 회상에서 더 어려움을 겪게 된다고 하여 회상 검사가 기 억장애 고위험자 및 기억장애 환자들을 판별하고 추적관찰하 는 데 주요한 검사 과제가 될 수 있음을 시사하였다.

본 연구에서는 20 분의 지연 시간 동안 비언어적 과제를 실시 하였다. 검사 과제와 비슷한 성격의 언어 과제를 제시하지 않아 시연 과정에 얼만큼의 강도로 방해했는지 파악하기는 어려우 나, 주관적으로 기억 문제를 호소하는 SMI라 할지라도 이러한 기억 지연 정도와 방해 과제가 기존에 제시한 정보의 시연을 방 해하고, 그 결과 IU를 부호화하고 응고화하는 것에 어려움을 초래할 수 있는 것으로 해석해 볼 수 있다.

\section{서열위치에 따른 집단 간 IU 회상률 차이}

서열위치에 따른 집단 간 IU 회상률의 차이를 알아본 결과 집단과 서열위치에 대한 상호작용이 유의하였다. 즉 정상 노인 집단은 계열위치에 따라 IU 회상률의 차이가 있었지만, SMI는 서열위치에 따른 차이 없이 모두 저조한 회상률을 보였다.

본 연구에서 SMI는 초두위치에서 낮은 회상률을 나타내어, 초두효과가 나타나지 않았다. 초두효과는 시연과 밀접한 관련 
이 있으며(Rundus, 1971; Wiswede et al., 2007) SMI는 시연에 어려움을 보이는 것을 파악할 수 있다. 국외의 한 연구에서는 회상 과제 시 시연 책략에 따른 단어 회상률을 비교하였는데, 서열위치 중 초두위치가 시연을 많이 하는 위치라고 보고하였 다(Rundus, 1971).

본 연구에서 SMI는 최신위치에서 낮은 회상률을 나타내어, 최신효과가 나타나지 않았다. 최신효과는 단기기억을 반영하며 (Glanzer \& Cunitz, 1966), SMI가 시연을 통해 새로운 정보를 단기기억에서 장기기억으로 저장하는 것에 어려움을 보인 것으 로 파악할 수 있다(Capitani et al., 1992). Atkinson \& Shiffrin (1968)은 정보는 감각기억을 거쳐 단기기억, 장기기억으로 저장 되는데, 단기기억 저장소(short-term store)에서 시연 버퍼(rehearsal buffer)를 통해 4 5 단어를 저장할 수 있다고 하였다. 버퍼가 가득 차면, 이전에 들어온 항목은 사라지고 새로운 항 목으로 대체되는 과정에서 쇠퇴나 간섭으로 인해 장기기억으로 저장되는 데 어려움을 겪을 수 있다고 하였다. 따라서 SMI는 단기기억의 정보를 쇠퇴나 간섭으로 인해 장기기억으로 저장하 거나 인출하는 데 실패하여 낮은 최신효과를 보인 것으로 해석 할 수 있다.

국내 노인을 대상으로 이야기 다시말하기검사를 실시한 한 연구에서는 학력에 따른 이야기 문법 산출의 차이를 보고하였 다(Sohn et al., 2005). 연구에 따르면 저학력 집단은 고학력 집 단보다 자극이 제시되는 순서에 상관없이 모든 정보단위를 회 상하고 산출해내는 데 취약하며, 그 이유로 저학력 집단이 이 야기 구조 및 전달에 중요한 역할을 하는 플롯(주제)이나 주제 관련 내용을 회상하는 능력이 고학력 집단에 비해 낮았기 때 문이라고 보고하였다. 다시 말해 저학력 집단은 이야기의 핵심 을 파악하는 '거시적 구조'를 보는 눈이 제한되어 있다고 언급 하고 있다. 이처럼 본 연구에서도 SMI의 학력 수준이 정상 노 인에 비해 낮았으며, SMI가 이야기의 핵심 주제의 '거시적 구조' 를 파악하는 시각에 어려움이 있어, 서열위치에 상관없이 모든 $\mathrm{IU}$ 를 회상하는 데 어려움을 겪어 서열위치효과가 나오지 않았 을 가능성이 있다.

본 연구의 의의는 다음과 같다. 본 연구는 주로 아동들을 대 상으로 이야기 다시 말하기 과제를 실시한 기존 연구들과는 달 리, 최근 노인의 인지장애를 변별하기 위해 성인을 대상으로 한 신경심리검사에서 하위항목으로 포함되어 있는 이야기 다시 말하기 과제를 SMI 및 정상 노인을 대상으로 실시하였다. 국내 의 신경심리검사 중 노인 인지기능검사(Literacy Independent Cognitive Assessment)의 하위 항목으로 이야기 회상 과제 (story retelling test)가 포함되어 있으며, 이러한 과제는 단어목 록회상검사와 같은 단순히 언어 정보를 입력, 저장, 인출하는 기억 검사에 비해 상대적으로 상위 인지기능을 요구하므로, 피
험자의 기억력 문제를 더욱 예민하게 선별할 수 있다고 하였다. 따라서 본 연구에서는 최근 노인 기억선별검사로 각광받고 있 는 이야기 다시 말하기 과제를 정상 노인 및 SMI에게 실시하여 집단 간 수행력을 비교하였다는 점에서 임상적 의의가 있다.

끝으로 연구에서의 제한점과 추후 연구를 통해 보완해야 할 점을 살펴보면 첫째, 본 연구에서는 다양하고 이질적인 하위 유 형의 SMI가 존재함에도 불구하고, 이를 구분하지 않고 전체로 묶어서 연구하였다는 점에서 한계가 있다. 국내 SMI군을 신경 심리학적 검사 및 신경정신학적 선별 검사 소견을 토대로 여러 유형의 하위 집단으로 구분하여 제시한 한 연구에서는 $\mathrm{SMI}$ 군 이 '기억 불만에 대한 호소는 약하지만, 기억 책략을 적게 사용 하는 집단', '기억 불만에 대한 호소가 약하고 기억 책략을 많이 사용하는 집단', '기억 불만에 대한 호소가 심하면서 매우 우울 한 집단'의 세 집단으로 구분할 수 있다고 언급하고 있다(Chin et al., 2010). 따라서 SMI군 내에서도 기억 불만을 강하게 호소 하는 집단과 약하게 호소하는 집단 간의 차이가 이야기 다시 말 하기 수행에서도 변별적으로 다르게 나타날 가능성도 있으므로 추후 연구에서 이를 확인하는 작업이 필요할 것으로 보인다.

마지막으로 이야기 회상 과제 수행에 대한 분석 시, 서열위치 와 기억 지연 유무만으로 그 수행을 비교하는 정량적인 평가 외 에도 이야기 문법 요소와 정보 제시 순서에 따른 질적인 차이를 비교 분석한 연구가 함께 이루어진다면 이야기 다시 말하기 과 제에서의 수행을 다차원적으로 분석하고, 이 결과를 SMI 조기 변별을 위해 더욱 유용하게 활용할 수 있을 것으로 생각한다.

중심 단어 : 주관적 기억장애·이야기 다시 말하기·정보단위· 서열위치·기억 지연.

\section{Ethical Statement}

The study was approved by the Institutional Review Board of Daegu University (1040621-201807-HR-011-02).

\section{Acknowledgments}

N/A

\section{Declaration of Conflicting Interests}

There are no conflict of interests.

\section{Funding}

N/A

\section{Author Contributions}

J.W.K. designed and managed this manuscript, and reviewed its final version as the corresponding author. J.H.K. worked for data collection and analysis under J.W.K.S supervision. Also, J.H.K. analyzed data, and wrote the paper.

\section{ORCID iDs}

JuHyeon Kim

JungWan Kim

https://orcid.org/0000-0003-2314-1044

https://orcid.org/0000-0003-3763-0914 


\section{REFERENCES}

Abdulrab, K. \& Heun, R. (2008). Subjective memory impairment. A review of its definitions indicates the need for a comprehensive set of standardised and validated criteria. European Psychiatry, 23(5), 321330 .

Arenberg, D. (1976). The effects of input condition on free recall in young and old adults. Journal of Gerontology, 31(5), 551-555.

Atkinson, R. C. \& Shiffrin, R. M. (1968). Human memory: A proposed system and its control processes. The Psychology of Learning and Motivation, 2, 89-195.

Baddeley, A. D. \& Warrington, E. K. (1970). Amnesia and the distinction between long- and short-term memory. Journal of Verbal Learning and Verbal Behavior, 9(2), 176-189.

Bruno, D., Reiss, P. T., Petkova, E., Sidtis, J. J., \& Pomara, N. (2013). Decreased recall of primacy words predicts cognitive decline. Archives of Clinical Neuropsychology, 28(2), 95-103.

Capitani, E., della Sala, S., Logie, R. H., \& Spinnler, H. (1992). Recency, primacy, and memory: Reappraising and standardising the serial position curve. Cortex, 28(3), 315-342.

Chin, J., Oh, K. J., Seo, S. W., Shin, H. Y., \& Na, D. L. (2010). The characteristics and subtypes of subjective memory impairment in older adults. Dementia and Neurocognitive Disorders, 9(4), 115-121.

Glanzer, M. \& Cunitz, A. R. (1966). Two storage mechanisms in free recall. Journal of Verbal Learning and Verbal Behavior, 5(4), 351-360.

Jessen, F., Feyen, L., Freymann, K., Tepest, R., Maier, W., Heun, R., et al. (2006). Volume reduction of the entorhinal cortex in subjective memory impairment. Neurobiology of Aging, 27(12), 1751-1756.

Jessen, F., Wiese, B., Bachmann, C., Eifflaender-Gorfer, S., Haller, F., Kölsch, H., et al.; German Study on Aging, Cognition and Dementia in Primary Care Patients Study Group. (2010). Prediction of dementia by subjective memory impairment: Effects of severity and temporal association with cognitive impairment. Archives of General Psychiatry, 67(4), 414422.

Joanette, Y., Ska, B., \& Côté, H. (2004). Protocole MEC: Protocole Montréal D'évaluation de la Communication. Montreal, Canada: Ortho Édition.

Jung, M. J. (2014). Serial position effects on abilities of word recall as a function of time delay in mild cognitive impairment (Unpublished master's thesis). Ewha Womans University, Seoul.

Kang, M. A. \& Beak, Y, M. (2014). The neurocognitive function between the patients who had subjective memory impairment and mild cognitive impairment. Annals of Geriatric Medicine and Research, 18(1), 7-15.

Kang, Y. W. (2006). A normative study of the Korean Mini-Mental State Examination (K-MMSE) in the elderly. Korean Journal of Psychology: General, 25(2), 1-12.

Kang, Y. W., Na, D. L., \& Hahn, S. H. (1997). A validity study on the Korean Mini-Mental State Examination (K-MMSE) in dementia patients. Journal of the Korean Neurological Association, 15(2), 300-308.

Kee, B. S. (1996). A preliminary study for the standardization of geriatric depression scale short form-Korea version. Journal of Korean Neuropsychiatric Association, 35(2), 298-307.

Kim, H. H., Kim, S. R., Yoo, H. J., \& Kim, J. W. (2013). Content validity of speech-language assessment items for the elderly. Journal of Rehabilitation Research, 17(3), 347-353.

Kim, H. \& Sung, J. E. (2014). Age-related changes in story retelling procedures and their relation to working memory capacity. Special Education Research, 13(3), 7-24.

Kim, M. Y. (2018). The frequency and solution to the tip of the tongue phe- nomenon symptoms of the elderly with subjective memory impairment (Unpublished master's thesis). Daegu University, Gyeongsan.

La Rue, A., Hermann, B., Jones, J. E., Johnson, S., Asthana, S., \& Sager, M. A. (2008). Effect of parental family history of Alzheimer's disease on serial position profiles. Alzheimer's and Dementia, 4(4), 285-290.

Lee, H. W., Kim, S. K., Lee, K., E., Chung, E. J., \& Park, J. Y. (2012). The agerelated changes in cognitive function. Korean Journal of Cognitive and Biological Psychology, 24(2), 127-148.

McNeil, M. R., Doyle, P. J., Fossett, T. R. D., Park, G. H., \& Goda, A. J. (2001). Reliability and concurrent validity of the information unit scoring metric for the story retelling procedure. Aphasiology, 15(10-11), 9911006.

Mitchell, A. J. (2008). The clinical significance of subjective memory complaints in the diagnosis of mild cognitive impairment and dementia: A meta-analysis. International Journal of Geriatric Psychiatry, 23(11), 11911202

Murdock, Jr. B. B. (1962). The serial position effect of free recall. Journal of Experimental Psychology, 64(5), 482-488.

Parkinson, S. R., Lindholm, J. M., \& Inman, V. W. (1982). An analysis of age differences in immediate recall. Journal of Gerontology, 37(4), 425-431.

Ribeiro, F., Guerreiro, M., \& De Mendonça, A. (2007). Verbal learning and memory deficits in mild cognitive impairment. Journal of Clinical and Experimental Neuropsychology, 29(2), 187-197.

Rundus, D. (1971). Analysis of rehearsal processes in free recall. Journal of Experimental Psychology, 89(1), 63-77.

Salthouse, T. A. (1980). Age and memory: Strategies for localizing the loss. In Poon, L. W., Fozard, J., Cermak, L. S., Arenberg, D., \& Thompson, L. W. New Directions in Memory and Aging: Proceedings of the George A. Talland Memorial Conference. Hillsdale, NJ: Lawrence Erlbaum.

Sohn, E. N., Kang, S. K., Paik, E. A., Park, S. H., Lee, H. H., \& Choi, K. H. (2005). A preliminary study on story retelling in the elderly. Journal of Special Education and Rehabilitation Science, 44(4), 243-255.

Takayama, Y. (2010). A delayed recall battery as a sensitive screening for mild cognitive impairment: Follow-up study of memory clinic patients after 10 years. Journal of Medical and Dental Sciences, 57(2), 177-184.

Tan, L. \& Ward, G. (2008). Rehearsal in immediate serial recall. Psychonomic Bulletin and Review, 15(3), 535-542.

Tobiansky, R., Blizard, R., Livingston, G., \& Mann, A. (1995). The Gospel Oak Study stage IV: The clinical relevance of subjective memory impairment in older people. Psychological Medicine, 25(4), 779-786.

Walsh, C. M., Wilkins, S., Bettcher, B. M., Butler, C. R., Miller, B. L., \& Kramer, J. H. (2014). Memory consolidation in aging and MCI after 1 week. Neuropsychology, 28(2), 273-280.

Wiswede, D., Rüsseler, J., \& Münte, T. F. (2007). Serial position effects in free memory recall-An ERP-study. Biological Psychology, 75(2), 185193.

Woo, H. R. \& Kim, J. W. (2019). The performance of the Korean Montreal protocol for evaluation of communication in the stroke patients with right vs. left hemispheric groups: A qualitative and quantitative analysis. Journal of the Korean Data Analysis Society, 21(1), 437-449.

Wright, R. E. (1982). Adult age similarities in free recall output order and strategies. Journal of Gerontology, 37(1), 76-79.

Yesavage, J. A., Brink, T. L., Rose, T. L., Lum, O., Huang, V., Adey, M., et al. (1982-1983). Development and validation of a geriatric depression screening scale: A preliminary report. Journal of Psychiatric Research, 17(1), 37-49. 


\section{APPENDICES}

\section{Appendix 1. 우물 이야기 과제}

지시 사항: 이야기를 듣고, 기억나는 대로 이야기를 다시 말해주세요.

채점:

: U를 의미하며, 각 1점

): 한 문장 내에서 ( ) 중 하나가 회상되면 됨.

동의어 사용도 허용

\begin{tabular}{|c|c|c|}
\hline \multirow{2}{*}{ 초두위치 } & (농부)인 (김씨)는 아침에 우물 파는 일을 마무리하기 위해 마당으로 나왔습니다. & IU 수 \\
\hline & 하지만 간밤에 (우물이 무너져서), (그 구멍 절반이 흙으로 뒤덮인 걸 보고), 김씨는 매우 실망하였습니다. & 6 \\
\hline \multirow{2}{*}{ 중간위치 } & 고민하다가 김씨는 자켓과 모자를 벗어서 우물 안에 넣고, 나무에 (올라가) (숨었습니다). & $\mathrm{IU}$ 수 \\
\hline & 동네 친구가 김씨 집에 놀러왔다가, 우물의 자켓과 모자를 보고, 사고가 났다고 생각했습니다. & 6 \\
\hline \multirow{2}{*}{ 최신위치 } & 동네 친구는 이웃들을 불러와서 같이 우물의 흙을 파기 시작하였습니다. & IU 수 \\
\hline & 이웃들이 우물을 거의 팠을 때쯤, 김씨는 나무에서 내려와 자기 일손을 도와줘서 고맙다고 말하였습니다. & 6 \\
\hline & 총 U 수 & 18 \\
\hline
\end{tabular}

IU: information unit 


\section{ASR}

Appendix 2. 우물 이야기 그림

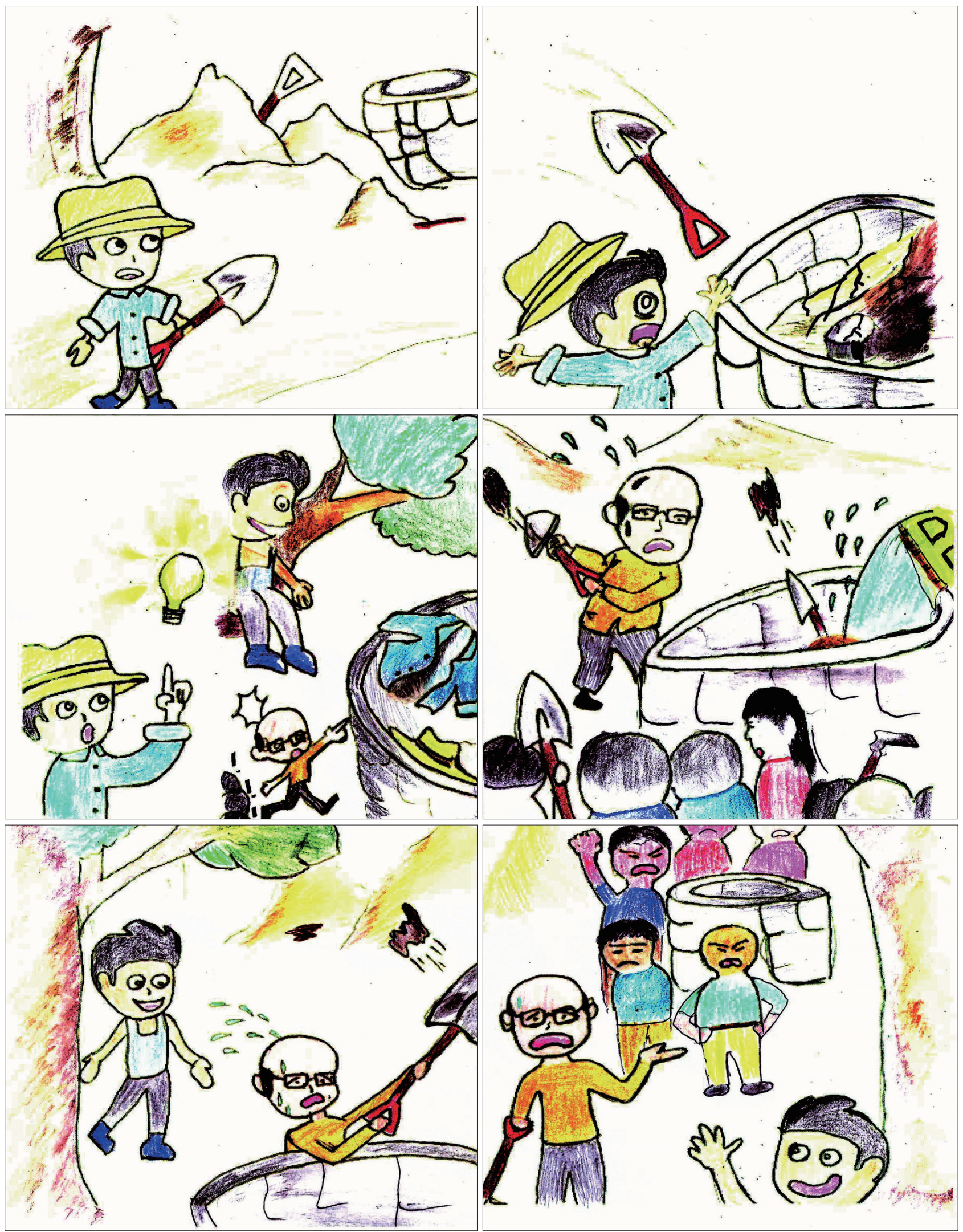

